\title{
Neurosonographic monitoring of haemodynamic changes in tandem middle cerebral and internal carotid artery occlusion due to arterial dissection
}

\section{Ultrasonograficzne monitorowanie zmian hemodynamicznych w jednoczesnej niedrożności tętnicy mózgu środkowej i tętnicy szyjnej wewnętrznej wywołanej rozwarstwieniem tętnicy}

Zeliko Zivanovic', Aleksandar Jesic', Aleksandra Lucic-Prokin', Predrag Avramov², Nikola Boban², Slobodan Gvozdenovic', Petar Slankamenac'

'Department of Neurology, Clinical Centre of Voivodina, Novi Sad, Serbia

2Department of Radiology, Clinical Centre of Voivodina, Novi Sad, Serbia

Neurologia i Neurochirurgia Polska 2012; 46, 6: 595-602

DOI: 10.5114/ninp.2012.31605

\begin{abstract}
A middle-aged man with pain in the right eye and right side of the neck was brought to the emergency department one hour after the onset of left-sided weakness. Computed tomography (CT) showed hyperdense right middle cerebral artery (MCA). On transcranial Doppler (TCD), occlusion of the right MCA and right internal carotid artery (ICA) was found. Thirty minutes after thrombolytic therapy was initiated, engagement of collateral circulation through the anterior communicating artery (AComA) was shown by TCD. Carotid duplex examination confirmed occlusion of the right ICA with intimal flap and intramural haematoma. CT angiography revealed flame-like occlusion of the right ICA, and occlusion of the right MCA with collateral supply from the left to right anterior cerebral artery through the AComA. Recanalization of the MCA and ICA was evident on both CT and ultrasound. Frequent ultrasound monitoring is useful for haemodynamic evaluation of carotid artery dissection, while TCD plays an important role in real-time monitoring of flow changes of intracranial vasculature.
\end{abstract}

Key words: carotid dissection, transcranial Doppler, haemodynamic, monitoring.

\section{Streszczenie}

Mężczyzna w średnim wieku zgłosił się na oddział pomocy doraźnej po około godzinie od wystąpienia osłabienia lewych kończyn i z występującym od kilku dni bólem prawego oka i szyi po stronie prawej. W badaniu tomografii komputerowej (TK) stwierdzono hiperdensyjną tętnicę środkową mózgu (MCA), a w przezczaszkowym badaniu dopplerowskim (TCD) - niedrożność prawej MCA i prawej tętnicy szyjnej wewnętrznej (ICA). Po 30 minutach od rozpoczęcia leczenia trombolitycznego zaobserwowano w TCD uczynnienie krą żenia obocznego za pośrednictwem tętnicy łączącej przedniej (AComA). W badaniu tętnic szyjnych metodą dupleksową potwierdzono niedrożność prawej ICA z płatem błony wewnętrznej i krwiakiem śródściennym. W angio-TK widoczna była niedrożność prawej ICA w kształcie płomienia, a także niedrożność prawej MCA z krążeniem obocznym z tętnicy mózgu przedniej lewej do prawej poprzez AComA. W TK i w badaniu ultrasonograficznym stwierdzono cechy udrożnienia MCA i ICA. Monitorowanie za pomoca powtarzanego badania ultrasonograficznego jest przydatne w hemodynamicznej ocenie rozwarstwienia tętnicy szyjnej, a TCD odgrywa istotną rolę w monitorowaniu zmian przepływu w naczyniach wewnątrzczaszkowych w czasie rzeczywistym.

Słowa kluczowe: rozwarstwienie tętnicy szyjnej, przezczaszkowe badanie dopplerowskie, hemodynamiczny, monitorowanie.

Correspondence address: Zeliko Zivanovic, MD, Clinical Centre of Vojvodina, Emergency Centre, Department of Neurology, Hajduk Velika 1, 21000 Novi Sad, Serbia, phone: +381638329117,fax: +381214872244,e-mail: drzzivanovic@yahoo.com Received: 17.07.2011; accepted: 21.02.2012 


\section{Introduction}

Clinical presentation of carotid artery dissection (CAD) includes pain on one side of the head, face, or neck, often accompanied by Horner syndrome, and may result in cerebral ischaemia [1]. Although conventional angiography has long been determined as the gold standard in the diagnosis of CAD, typical structural changes such as mural haematoma, intimal flap, double lumen, and long-tapered stenosis can be visualised on carotid ultrasound, whereas downstream haemodynamic effects are directly detectable by transcranial Doppler (TCD) $[1,2]$.

\section{Case report}

A 51-year-old man with a one-month history of hypertension and five-day history of pain in right eye and right side of the neck was brought to the emergency department one hour after the onset of left-sided weakness. On admission, he was somnolent but oriented, dysarthric, with gaze deviation to the right side and left hemiplegia (National Institutes of Health Stroke Scale [NIHSS] score 16). Non-contrast computed tomography (CT) showed a hyperdense right middle cerebral artery (MCA) (Fig. 1A) with attenuation of corticomedullary differentiation in the right parietal lobe (M5) and an Alberta Stroke Program Early CT Score (ASPECTS) of 9 [3]. Treatment with intravenous tissue plasminogen activator (tPA) was started after $90 \mathrm{mi}-$ nutes of the onset of symptoms.

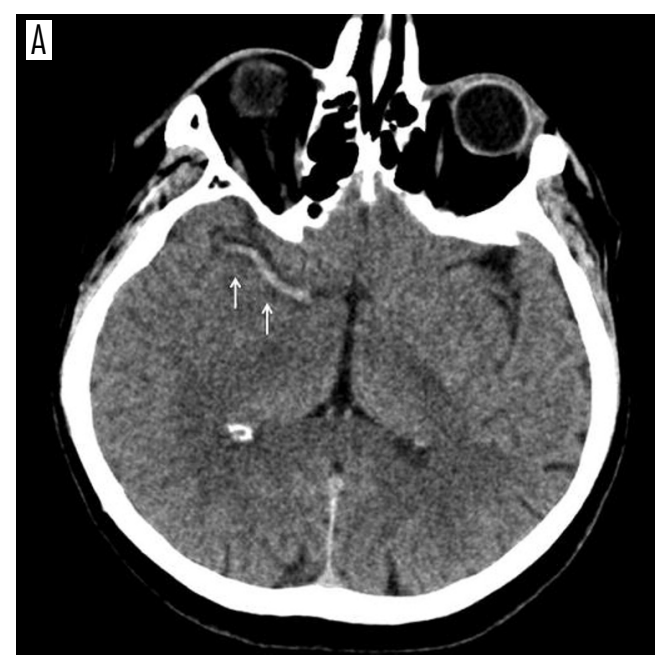

Fig. 1. A) Hyperdense sign of right middle cerebral artery (white arrows); B) massive right hemispheric infarction

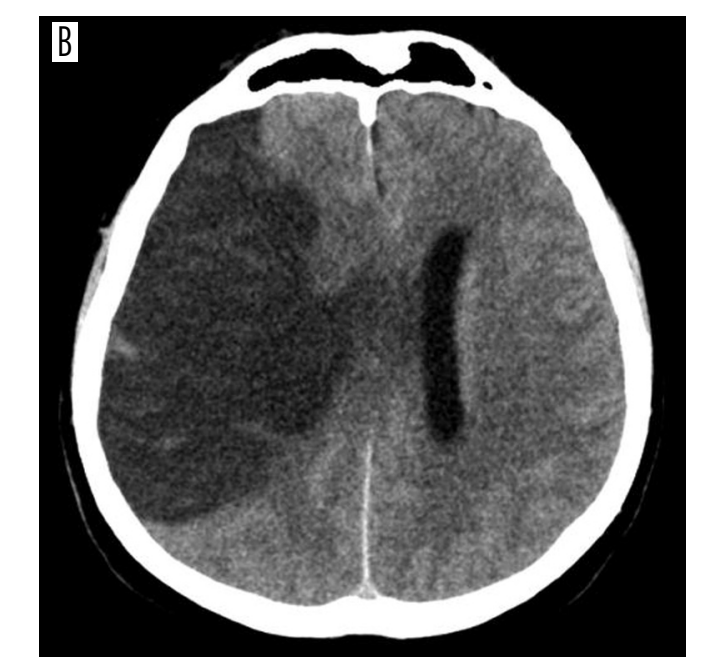

Transcranial power motion Doppler (PMD-TCD) was performed immediately after initiation of thrombolytic therapy. The mean flow velocities (MFV) in the anterior, middle and posterior cerebral artery (ACA, $\mathrm{MCA}$, and PCA, respectively) on the left side were within the normal range. In the right MCA, only a minimal flow signal in the distal part was detected (Fig. 2A) with Thrombolysis in Brain Ischemia (TIBI) grade 1 [4]. The right ACA was not identified, while the right PCA had normal flow velocities. Minimal residual antegrade flow signals were obtained from the right carotid siphon and ophthalmic artery through the transorbital window. Extracranial Doppler examination of the right carotid artery showed a high resistance 'stump' waveform without diastolic flow (called pre-occlusive thump) in the common carotid artery (CCA) and absence of a flow signal in the internal carotid artery (ICA). The left CCA/ICA, both of the vertebral arteries (VA) and basilar artery (BA) had normal flow velocities.

Thirty minutes after the application of $\mathrm{tPA}, \mathrm{PMD}$ TCD was repeated. Delayed systolic flow acceleration and slow diastolic deceleration (called a blunted flow signal) with $\mathrm{MFV}$ of $24 \mathrm{~cm} / \mathrm{s}$ (TIBI grade 2) were demonstrated in the proximal part of the right MCA (Fig. 2B). The flow in the right ACA was reversed with $\mathrm{MFV}$ of $93 \mathrm{~cm} / \mathrm{s}$ and MFV in the left ACA was higher than in the left MCA, which proved the restitution of collateral flow from the left ACA to the right ACA and MCA through the anterior communicating artery (AComA). However, the patient's neurological deficit did not improve. 

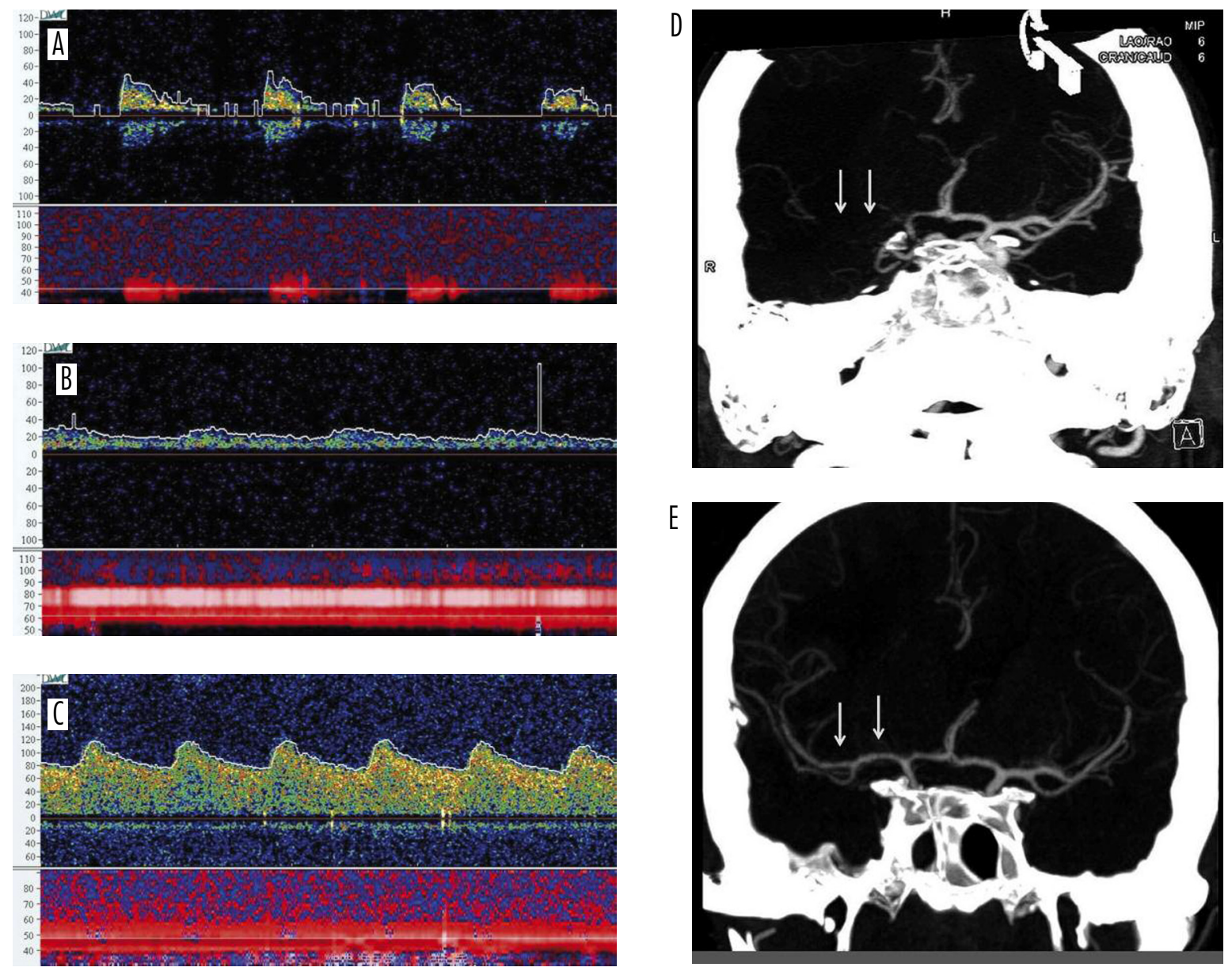

Fig. 2. On the left side, waveforms from transcranial power motion Doppler show: A) initial, minimal bidirectional flow signal in right middle cerebral artery (MCA) - Thrombolysis in Brain Ischemia (TIBI) grade 1; B) during thrombolysis, blunted flow signal in right MCA - TIBI grade 2; C) 13 days after, low resistance end-diastolic flow signal in right $M C A$ - TIBI grade 4 suggesting recanalization. On the right side, computed tomography (CT) angiography shows: D) absence of right MCA on (T angiography (white arrows), and E) two weeks later, recanalization of previously occluded right MCA (white arrows)

Carotid duplex ultrasound performed the next day showed absent flow signal in the right ICA, and systolic spikes on spectral analysis. Intimal flap with intramural haematoma was observed in the proximal part of the right ICA (Fig. 3A). Control CT showed massive hemispheric infarction on the right (Fig. 1B). CT angiography revealed flame-like occlusion of the right ICA (Fig. 3B) and occlusion of the right MCA with collateral supply from the left to right ACA via the AComA (Fig. 2D). Given the size of the infarct, aspirin $100 \mathrm{mg}$ daily was started 24 hours after thrombolysis. The patient's symptoms started to improve slowly during the next days.

About ten days later, PMD-TCD was repeated. The MFV in the right MCA was $93 \mathrm{~cm} / \mathrm{s}$ with stenotic low resistance end-diastolic flow (Fig. 2C) suggesting the recanalization of the right MCA (TIBI grade 4).
The right ophthalmic artery had normal flow direction toward the probe and was highly suggestive of recanalization of the right ICA. Control carotid duplex ultrasound showed recanalization of the right ICA. CT angiography confirmed partial recanalization of the right ICA with residual, long-tapered non-significant stenosis (Fig. 3C) and recanalization of the right MCA (Fig. 2E). After two weeks, the patient was transferred to the rehabilitation centre with severe left-sided hemiparesis (NIHSS score 11).

\section{Discussion}

Our case demonstrated initial tandem MCA and long ICA occlusion suggestive of CAD, fast engagement of collateral circulation to supply the territory of the occluded blood vessel during thrombolysis, and 

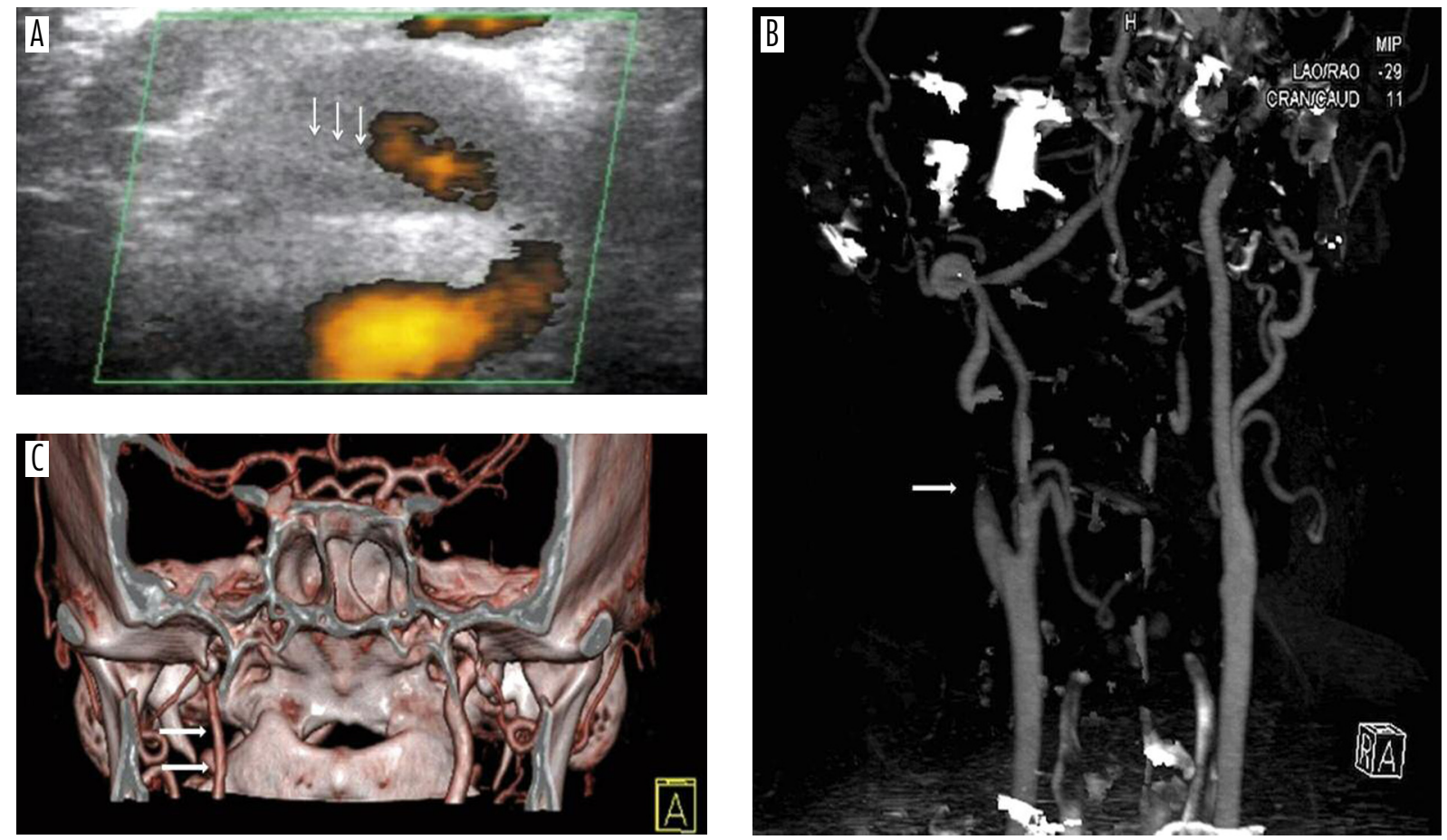

Fig. 3. A) Power Doppler images show: minimal flow in the proximal right internal carotid artery (ICA) and suspected intimal flap with intramural haematoma below on longitudinal views (white arrows); B) computed tomography (CT) angiography shows flame-like occlusion of right ICA (white arrow); C) partial recanalization of the right ICA (white arrows) two weeks later on 3D CT angiography

delayed recanalization, as detected by PMD-TCD. The intimal flap was revealed by carotid duplex ultrasound and substantiated the suspicion of CAD.

Carotid dissection is a dynamic process with many changes of radiological and neurosonological findings [5]. TCD has an important role in detection of haemodynamic changes of intracranial vasculature in real time and provides valuable assistance for monitoring of patients during thrombolysis [6-8]. The high level of agreement between TCD and CT angiographic findings in acute ischaemic stroke patients was validated by several studies, especially for anterior circulation [9].

The recanalization rate of $\mathrm{CAD}$ varies among studies from $40 \%$ to $80 \%$, and usually happens within the first two to three months after dissection $[1,5]$. The treatment strategy of CAD depends on whether the CAD presents with stenosis or occlusion, with or without cerebral infarction [1]. Frequent ultrasound monitoring of $\mathrm{CAD}$ is useful for detection of recanalization, and may assist in the choice of the optimal treatment [10].

This case illustrates typical neurosonographic findings in a patient with a long-segment ICA dissection and emphasizes the value of a noninvasive vascular test that can be used to provide real-time physiological information which is often unobtainable with other imaging modalities without increased patient risk (repeated radiation doses, contrast injections) and associated costs.

\section{Disclosure}

Authors report no conflict of interest.

\section{References}

1. Debette S., Leys D. Cervical-artery dissections: predisposing factors, diagnosis, and outcome. Lancet Neurol 2009; 8: 668-678.

2. Schwartz N.E., Vertinsky A.T., Hirsch K.G., et al. Clinical and radiographic natural history of cervical artery dissections. J Stroke Cerebrovasc Dis 2009; 18: 416-423.

3. Barber P.A., Demchuk A.M., Zhang J., et al. Validity and reliability of a quantitative computed tomography score in predicting outcome of hyperacute stroke before thrombolytic therapy. ASPECTS Study Group. Alberta Stroke Programme Early CT Score. Lancet 2000; 35 5: 1670-1674.

4. Demchuk A.M., Burgin W.S., Christou I., et al. Thrombolysis in brain ischemia (TIBI) transcranial Doppler flow grades predict clinical severity, early recovery, and mortality in patients treated with intravenous tissue plasminogen activator. Stroke 2001; 32: 89-93. 
5. Baracchini C., Tonello S., Meneghetti G., et al. Neurosonographic monitoring of 105 spontaneous cervical artery dissections: a prospective study. Neurology 2010; 75: 1864-1870.

6. Christou I., Felberg R.A., Demchuk A.M., et al. A broad diagnostic battery for bedside transcranial Doppler to detect flow changes with internal carotid artery stenosis or occlusion. J Neuroimaging 2001; 11: 236-242.

7. Zivanovic Z., Barlinn K., Balucani C., et al. What is role of ultrasound in systemic thrombolysis? Curr Top Neurol Psychiatr Relat Discip 2010; 18: 33-41.

8. Turek G., Kochanowicz J., Lewszuk A., et al. Sonographic diagnosis and endovascular recanalization of the internal carotid artery in a patient with carotid thromboembolism following coiling of cerebral aneurysm. Neurol Neurochir Pol 2011; 45: 286-291.

9. Barlinn K., Zivanovic Z., Zhao L., et al. Intracranial vessel localization with power motion Doppler (PMD-TCD) compared with $\mathrm{CT}$ angiography in patients with acute ischemic stroke. Int J Stroke 2012; doi: 10.1111/j.1747-4949.2011.00751.x

10. Rundek T., Katsnelson M. Is frequent ultrasound monitoring of spontaneous cervical artery dissection clinically useful? Neurology 2010; 75: 1858-1859. 